\title{
PENGARUH KONFLIK PERAN, KETIDAKJELASAN PERAN, KELEBIHAN PERAN, DAN GAYA KEPEMIMPINAN TERHADAP KINERJA AUDITOR DI KANTOR AKUNTAN PUBLIK WILAYAH DKI JAKARTA
}

\author{
Hendra Gunawan; Zulfitry Ramdan \\ Accounting Department, Faculty of Economic and Communication, BINUS University \\ Jln. K.H. Syahdan No. 9, Kemanggisan-Palmerah, Jakarta Barat 11480
}

\begin{abstract}
The purpose of this research is to determine and obtain empirical evidence on the factors related to the behavior of auditors that could affect the performance of auditors who work in Public Accounting Firm (KAP) Jakarta. This research discusses the factors regarding role conflict, role ambiguity, role excess, and leadership style. The writer took samples using convenience sampling technique. Criterion sampling was auditor working on the Firm in Jakarta with minimal education S1 majoring in Accounting with a minimum of one year working experience. Writers obtained research data through questionnaires distributed directly or via email to the auditors. The writers deployed 250 questionnaires to the auditors who worked on the Firm in Jakarta where questionnaires were successfully returned as many as 186 questionnaires, but there are 18 questionnaires that did not meet the criteria, so that 168 samples were used in this study. To obtain the results of the study, researchers used multiple regression analysis. The results of this study indicate that the independent variables included in this study, the lack of clarity of roles, have a significant influence on the performance of auditors. While, the other three independent variables: role conflict, role excess, and leadership style do not significantly affect the performance of the auditor.
\end{abstract}

Keywords: auditor, factors, behaviors, regression

\begin{abstract}
ABSTRAK
Tujuan penelitian ini adalah untuk mengetahui serta mendapatkan bukti empiris mengenai faktor-faktor yang berhubungan dengan perilaku auditor yang dapat memengaruhi kinerja auditor yang bekerja di Kantor Akuntan Publik (KAP) wilayah DKI Jakarta. Penelitian ini akan membahas faktor-faktor mengenai konflik peran, ketidakjelasan peran, kelebihan peran, dan gaya kepemimpinan. Peneliti mengambil sampel dengan menggunakan teknik convenience sampling. Kriteria sampel adalah auditor yang bekerja pada KAP di wilayah DKI Jakarta dengan jenjang pendidikan minimal S1 jurusan Akuntansi dengan pengalaman bekerja minimal satu tahun. Peneliti memperoleh data penelitian melalui kuesioner yang disebarkan secara langsung maupun melalui email kepada para auditor. Peneliti menyebarkan 250 kuesioner kepada auditor yang bekerja pada KAP di wilayah DKI Jakarta dimana kuesioner yang berhasil kembali seluruhnya sebanyak 186 buah, namun terdapat 18 kuesioner yang tidak memenuhi kriteria sehingga peneliti menggunakan 168 kuesioner sebagai sampel pada penelitian ini. Untuk memperoleh hasil penelitian, peneliti menggunakan analisis regresi berganda. Hasil dari penelitian ini menunjukkan bahwa satu variabel independen yang terdapat dalam penelitian ini, yakni ketidakjelasan peran, mempunyai pengaruh yang signifikan terhadap kinerja auditor. Sedangkan tiga variabel independen lainnya, yaitu konflik peran, kelebihan peran, dan gaya kepemimpinan ternyata tidak memengaruhi kinerja auditor secara signifikan.
\end{abstract}

Kata kunci: auditor, faktor, perilaku, regresi 


\section{PENDAHULUAN}

Individu yang diharuskan berinteraksi dengan banyak orang baik di dalam, maupun di luar organisasi dengan keinginan dan harapan yang beraneka ragam akan mengalami tekanan peran (role stress). Adanya konflik peran dan ketidakjelasan peran merupakan suatu hal yang cukup berpengaruh, tidak hanya bagi auditor itu sendiri dalam hubungannya dengan tekanan pekerjaan, kepuasan kerja, dan menurunnya kinerja, tetapi juga bagi organisasi tempat mereka bekerja yang berpengaruh pada kualitas kerja yang tidak sesuai dengan harapan. Dalam penelitian Fanani et al. (2008), Fried (1998) menguji pengaruh konflik peran dan ketidakjelasan peran terhadap kinerja pegawai perusahaan industrial di Israel. Penelitian tersebut menyatakan bahwa konflik peran dan ketidakjelasan peran berpengaruh pada penurunan level kinerja. Sementara penelitian Iskak \& Elizabeth (2004) dalam Agustina (2009) telah melakukan wawancara langsung dengan staf auditor yang bekerja pada Kantor Akuntan Publik di DKI Jakarta, hasilnya staf auditor profesional merasa penempatan pekerjaan seringkali tidak sesuai dengan keahlian sebab dalam prakteknya terkadang tidak dilakukan identifikasi khusus atas keahlian tiap personel terlebih dahulu dalam penugasan audit, kemudian kurangnya promosi jabatan pada KAP, baik dari junior menjadi senior, maupun senior menjadi supervisor, dari data responden terdapat $25,9 \%$ responden yang tidak jelas dengan posisinya saat ini. Hal tersebut merupakan dampak dari tidak adanya kegiatan promosi jabatan yang membingungkan para staf profesional akan posisi mereka dalam KAP. Hal ini terutama dirasakan oleh para karyawan yang telah bekerja lebih dari tiga tahun dalam Kantor Akuntan Publik. Selanjutnya, KAP juga tidak banyak melakukan rekrutmen pegawai sebab KAP tidak membuat perencanaan kebutuhan personel, akibatnya pada waktu peak season staf auditor harus menyelesaikan pekerjaan audit untuk beberapa klien sekaligus pada periode waktu yang sama. Penelitian ini menggunakan tiga elemen tekanan peran (role stress), seperti yang dikemukakan oleh Fogarty (2000) dan Almer \& Kaplan (2002), yang terdiri dari konflik peran (role conflict), ketidakjelasan peran (role ambiguity), dan kelebihan peran (role overload).

Dalam menjalankan tugasnya, auditor biasanya dihadapkan oleh potensi konflik peran maupun ketidakjelasan peran. Menurut Puspa dan Rianto (1999), konflik peran tidak akan timbul apabila seorang profesional yang bekerja dalam suatu organisasi mau beradaptasi dengan lingkungan pengendalian organisasi tempat ia bekerja. Ketidakjelasan peran terjadi karena tidak adanya informasi yang diperlukan untuk menjalankan perannya dengan cara yang memuaskan (Khan et al., 1964 dalam Dyah, 2002 dalam Agustina, 2009).

Kelebihan peran (role conflict) merupakan suatu keadaan dimana seseorang memiliki terlalu banyak pekerjaan untuk dilaksanakan pada suatu waktu tertentu (Almer dan Kaplan, 2002 dalam Rapina, 2008). Tidak adanya perencanaan akan kebutuhan tenaga kerja dapat membuat auditor mengalami kelebihan peran, terutama pada masa peak season dimana KAP akan kebanjiran pekerjaan dan staf auditor yang tersedia harus mengerjakan semua pekerjaan pada periode waktu yang sama.

Menurut Luthans (2002: 575) dalam Trisnaningsih (2007), gaya kepemimpinan (leadership style) merupakan cara seorang pemimpin memengaruhi orang lain atau bawahannya sehingga orang tersebut mau melakukan kehendak pimpinan untuk mencapai tujuan organisasi. Menurut Alberto et al. (2005) dalam Trisnaningsih (2007), gaya kepemimpinan berpengaruh positif kuat terhadap kinerja para karyawan. Dari temuan tersebut, maka muncul pendapat bahwa gaya kepemimpinan seorang pemimpin sangat berpengaruh terhadap kinerja para bawahannya, di samping itu untuk mendapatkan kinerja yang baik diperlukan juga adanya pelatihan terhadap para bawahan. Oleh karena itu gaya kepemimpinan dalam KAP sangat diperlukan karena dapat memberikan nuansa pada kinerja auditor. Gaya kepemimpinan yang informal lebih menekankan pada keteladanan pimpinan, namun memberikan kebebasan yang lebih luas bagi auditor untuk mengkreasi pekerjaannya serta tanggung jawab yang lebih besar, akibat dari instrumen organisasi secara formal belum memadai. 
Penelitian akuntansi keperilakuan (behavior) tentang gaya kepemimpinan, terhadap kinerja perusahaan bisnis manufaktur sudah sering dilakukan, tetapi masih jarang sekali dilakukan penelitian dalam perusahaan bisnis non-manufaktur, seperti KAP dengan responden auditor independen. Akuntan publik dalam melaksanakan pemeriksaan akuntansi, memperoleh kepercayaan dari klien dan para pemakai laporan keuangan untuk membuktikan kewajaran laporan keuangan yang disusun dan disajikan oleh klien. Klien dapat mempunyai kepentingan yang berbeda, bahkan mungkin bertentangan dengan kepentingan para pemakai laporan keuangan. Demikian pula, kepentingan pemakai laporan keuangan yang satu mungkin berbeda dengan pemakai lainnya. Oleh karena itu, dalam memberikan pendapat mengenai kewajaran laporan keuangan yang diperiksa, akuntan publik harus bersikap independen terhadap kepentingan klien, pemakai laporan keuangan, maupun kepentingan akuntan publik itu sendiri. Di samping itu, dengan adanya kode etik masyarakat dapat menilai sejauh mana seorang auditor telah bekerja sesuai dengan standar-standar etika yang telah ditetapkan oleh profesinya.

Seorang akuntan publik yang profesional dapat dilihat dari kinerjanya dalam menjalankan tugas dan fungsinya. Kinerja auditor merupakan suatu pengungkapan kerja yang dilakukan dalam rangka untuk mencapai hasil kerja yang lebih baik maupun lebih menonjol dalam tercapainya suatu tujuan organisasi. Menurut Goldwasser (1993) dalam penelitian Fanani et al. (2008), pencapaian kinerja auditor yang baik harus sesuai dengan standar dan kurun waktu tertentu yang mencakup: (1) Kualitas kerja, yaitu mutu penyelesaian pekerjaan dengan bekerja berdasarkan pada seluruh kemampuan dan keterampilan, serta pengetahuan yang dimiliki oleh auditor. (2) Kuantitas kerja, yaitu jumlah hasil kerja yang dapat diselesaikan dengan target yang menjadi tanggung jawab auditor. (3) Ketepatan waktu, yaitu ketepatan dalam menyelesaikan pekerjaan sesuai dengan waktu yang disediakan.

Kinerja auditor merupakan suatu hasil kerja yang dicapai oleh auditor dalam melaksanakan tugas dan tanggung jawab yang dibebankan kepadanya. Setiap pekerjaan apapun yang terdapat dalam suatu profesi, kinerja adalah salah satu indikator keberhasilan yang menjadi perhatian apakah sesuai dengan apa yang diharapkan atau justru sebaliknya. Penelitian ini merupakan pengembangan dari penelitian yang dilakukan oleh Lidya Agustina (2009). Berdasarkan hal tersebut, maka penelitian ini merupakan replikasi dari penelitian yang telah dilakukan sebelumnya dengan maksud untuk memperjelas dan mempertajam permasalahan yang berhubungan dengan pengaruh konflik peran, ketidakjelasan peran, kelebihan peran, dan gaya kepemimpinan terhadap kinerja auditor di Kantor Akuntan Publik wilayah DKI Jakarta.

Selain itu, alasan dilakukan penelitian ini adalah: pertama, kurangnya / hanya sedikit pengamatan yang dilakukan untuk menganalisis pengaruh konflik peran (role conflict), ketidakjelasan peran (role ambiguity), kelebihan peran (role overload), dan gaya kepemimpinan (leadership style). Kedua, cakupan area / wilayah yang digunakan dalam penelitian sebelumnya yang terbatas pada KAP yang bermitra dengan Kantor Akuntan Publik big four sehingga hasil dari penelitian tersebut hanya sebatas pada ke-empat KAP tersebut. Untuk memperluas ruang lingkup pada penelitian sebelumnya, penelitian ini dilakukan juga pada KAP non big four yang terdapat di DKI Jakarta. Ketiga, penambahan satu variabel independen dalam penelitian ini yaitu gaya kepemimpinan (leadership style). Keempat, beberapa penelitian terdahulu menunjukkan hasil yang tidak konsisten antara penelitian Fanani et al. (2008), Fisher (2001), Fried (1998), Agustina (2009), Viator (2001). Kelima, metode penelitian yang berbeda dari penelitian sebelumnya yang dilakukan dengan menggunakan metode deskriptif analitis dan pengumpulan data penelitian menggunakan metode survei dengan teknik pengumpulan data dan analisis data berupa opini dari responden melalui tanya jawab, sedangkan metode dalam penelitian ini adalah berupa penelitian kausalitas dengan menyebarkan kuesioner kepada para responden dan pemilihan sampel dengan menggunakan convenience sampling method. Berdasarkan uraian tersebut, maka peneliti memutuskan untuk melakukan penelitian dengan judul "Pengaruh Konflik Peran, Ketidakjelasan Peran, Kelebihan Peran, dan Gaya Kepemimpinan Terhadap Kinerja Auditor di Kantor Akuntan Publik Wilayah DKI Jakarta". 


\section{METODE}

Penelitian ini merupakan penelitian kausalitas, yang bertujuan untuk meneliti jenis masalah berupa pengaruh antara dua atau lebih variabel dengan mengidentifikasikan fakta atau peristiwa tersebut sebagai variabel yang dipengaruhi (variabel dependen) serta melakukan penyelidikan terhadap variabel yang memengaruhi (variabel independen). Sehingga, penelitian ini merupakan studi empiris berbentuk kausalitas yang bertujuan untuk mengetahui pengaruh konflik peran (role conflict), ketidakjelasan peran (role ambiguity), kelebihan peran (role overload), dan gaya kepemimpinan (leadership style) terhadap kinerja auditor.

Penelitian ini menggunakan jenis data primer yang dikumpulkan dan diolah sendiri langsung oleh penulis dari objeknya. Menurut Cooper dan Emory (1997) dalam Trisnaningsih (2007), data primer adalah data yang diperoleh langsung dari sumber data yang dikumpulkan secara khusus dan berhubungan langsung dengan permasalahan yang diteliti. Seperti penelitian yang dilakukan Trisnaningsih (2007), data primer diperoleh dengan menggunakan daftar pertanyaan yang telah terstruktur dengan tujuan untuk mengumpulkan informasi dari auditor yang bekerja pada KAP sebagai responden dalam penelitian ini. Sumber data dalam penelitian ini adalah skor masing-masing indikator variabel yang diperoleh dari pengisian kuesioner yang telah dibagikan kepada auditor yang bekerja pada KAP sebagai responden.

Dalam penelitian ini, pengumpulan data dilakukan dengan menggunakan metode survei. Data tersebut diperoleh dengan menggunakan instrumen (alat pengumpulan data) berupa lembar kuesioner yang akan dibagikan kepada responden untuk diisi dalam rangka memperoleh informasi dari auditor yang bekerja pada KAP yang berada di wilayah DKI Jakarta. Dua karakteristik yang harus ada pada instrumen yang digunakan tersebut adalah valid, dimana instrumen tersebut dapat mengukur apa yang seharusnya diukur, serta reliable dalam artian instrumen tersebut konsisten dalam memberikan penilaian atas apa yang diukur. Adapun instrumen berupa kuesioner yang digunakan dalam penelitian ini berjumlah 41 pertanyaan yang dikelompokkan ke dalam 5 kategori yang mewakili masing-masing variabel dependen dan variabel independen yang terdapat dalam penelitian ini. Pertanyaan-pertanyaan yang terdapat dalam kuesioner tersebut sebagian besar diadopsi dari penelitian yang dilakukan oleh Trisnaningsih (2007) dan Agustina (2009) yang berhubungan dengan konflik peran, ketidakjelasan peran, kelebihan peran, serta gaya kepemimpinan.

Penyebaran kuesioner penelitian dilakukan dengan mengirimkan langsung kuesioner tersebut oleh peneliti kepada masing-masing KAP di wilayah DKI Jakarta. Kuesioner akan dititipkan kepada bagian $H R D$ atau perwakilan dari masing-masing KAP untuk kemudian disebarkan kepada responden. Peneliti akan memberikan toleransi waktu pengisian selama beberapa minggu. Dengan cara ini, diharapkan tingkat pengembalian kuesioner bisa lebih tinggi untuk selanjutnya dilakukan analisis. Penyebaran kuesioner juga dilakukan melalui email yang dikirimkan oleh peneliti kepada responden melalui perwakilan masing-masing KAP yang telah dihubungi sebelumnya, kemudian responden atau perwakilan dari KAP tersebut akan mengirimkan balasan atau kuesioner penelitian kepada email peneliti.

\section{Pengertian Kinerja}

Secara etimologi, kinerja berasal dari kata prestasi kerja (performance). Sebagaimana dikemukakan oleh Mangkunegara (2005: 67) dalam Trisnaningsih (2007), istilah kerja berasal dari kata job performance atau actual performance (prestasi kerja atau prestasi yang sesungguhnya yang ingin dicapai seseorang) yaitu hasil kerja secara kualitas dan kuantitas yang dicapai oleh seorang pegawai dalam melaksanakan tugasnya sesuai dengan tanggung jawab yang diberikan. Menurut Mangkunegara (2005: 15) dalam Trisnaningsih (2007), kinerja dibedakan menjadi 2, yaitu kinerja 
individu dan kinerja organisasi. Kinerja individu adalah hasil kerja karyawan baik dari segi kualitas maupun kuantitas berdasarkan standar kerja yang telah ditentukan, sedangkan kinerja organisasi adalah gabungan dari kinerja individu dengan kinerja kelompok.

\section{Teori Peran}

Peran merupakan suatu perilaku yang diharapkan sesuai dengan posisi, jabatan, maupun status sosial seseorang dan sekaligus mencerminkan hak dan kewajiban seseorang. Jika peran yang dijalankan seseorang tidak mencerminkan harapan yang diinginkan, maka akan timbul konflik peran. Oleh karena itu, untuk menghindari adanya konflik peran, maka individu harus menjalankan suatu cara tertentu sesuai apa yang diharapkan. Albernethy dan Stoelwinder (1995) dalam Puspa dan Rianto (1999) menemukan bahwa tingkat peran dipengaruhi oleh seberapa jauh para profesional ingin mempertahankan sikap keprofesionalan mereka dalam perusahaan dan seberapa jauh lingkungan pengendalian yang berlaku di perusahaan mengancam otonomi para profesional tersebut. Menurut Khan (1964) dalam Agustina (2009), teori peran (role theory) merupakan penekanan sifat individual sebagai pelaku sosial yang mempelajari perilaku yang sesuai dengan posisi yang ditempati di masyarakat. Menurut Shaw dan Constanzo (1970) dalam Agustina (2009), peran adalah konsep sentral dari teori peran. Dengan demikian, pembahasan mengenai teori peran tidak lepas dari definisi peran dan berbagai istilah perilaku di dalamnya.

\section{Konflik Peran}

Seperti yang diungkapkan Wolfe dan Snoke (1962) dalam Cahyono dan Ghozali (2002), konflik peran timbul karena adanya dua perintah yang berbeda yang diterima secara bersamaan dan pelaksanaan salah satu perintah saja akan mengakibatkan terabaikannya perintah yang lain. Sementara menurut Assegaf (2005) dalam penelitiannya mengemukakan bahwa konflik ini muncul karena selain sebagai anggota organisasi, seorang karyawan profesional juga merupakan anggota suatu profesi yang diatur oleh kode etik dan standar kinerja profesi. Sedangkan sebagai anggota organisasi, ia harus patuh pada norma dan peraturan yang berlaku, memiliki kesetiaan kepada organisasi, serta tunduk pada wewenang dan pengawasan hierarkis.

\section{HASIL DAN PEMBAHASAN}

Penyebaran kuesioner penelitian dimulai sejak pertengahan Maret 2012 dan berakhir pada Mei 2012. Peneliti menyebarkan 250 kuesioner kepada 10 KAP yang terdapat di wilayah DKI Jakarta, termasuk 50 kuesioner yang dikirimkan melalui email, dan kuesioner yang berhasil kembali seluruhnya sebanyak 186 buah. Dari jumlah kuesioner yang berhasil kembali, terdapat 18 kuesioner yang tidak memenuhi kriteria untuk dilakukan pengujian dalam penelitian ini. Hal tersebut dikarenakan kuesioner yang kembali tidak diisi atau diisi tetapi tidak lengkap. Dengan demikian, kuesioner yang memenuhi kriteria berjumlah 168 buah. Namun, dari 168 kuesioner tersebut terdapat 3 kuesioner yang memiliki outliner sehingga kuesioner tersebut harus dieliminasi dari sampel karena tidak dapat digunakan dalam proses pengolahan data. Oleh karena itu, peneliti memutuskan untuk mengurangi data penelitian yang bersifat ekstrim yang dilakukan dengan membuang data yang bernilai z-score diatas 3 atau dibawah -3 sehingga total kuesioner yang dapat digunakan dalam proses pengolahan data berjumlah 165 buah. Berikut hasil pengumpulan kuesioner pada tabel 1 . 
Tabel 1 Hasil Pengumpulan Kuesioner

\begin{tabular}{lcc}
\hline Kuesioner yang disebarkan & 250 & $100 \%$ \\
Kuesioner yang dikirimkan langsung & 200 & $80 \%$ \\
Kuesioner yang dikirimkan melalui email & 50 & $20 \%$ \\
Kuesioner yang kembali & 167 & $84 \%$ \\
Kuesioner yang tidak diisi & 12 & $7 \%$ \\
Kuesioner yang tidak diisi secara lengkap & 6 & $4 \%$ \\
Kuesioner yang memenuhi kriteria & 149 & $89 \%$ \\
Kuesioner yang kembali melalui email & 19 & $38 \%$ \\
Kuesioner yang mengalami outlier & 3 & $2 \%$ \\
Kuesioner yang dapat diolah & 165 & $66 \%$ \\
\hline
\end{tabular}

\section{Uji Asumsi Klasik}

Suatu model regresi disebut sebagai model yang baik apabila memenuhi asumsi klasik. Oleh sebab itu, uji asumsi klasik sangat dibutuhkan sebelum melakukan analisis regresi. Uji asumsi klasik terdiri dari beberapa macam pengujian: (1) Normalitas residual, (2) Multikolinearitas, (3) Autokorelasi, (4) Heteroskedastisitas.

\section{Uji Normalitas Residual}

Tujuan pengujian normalitas residual yaitu untuk menguji apakah dalam sebuah model regresi, variabel penggangu atau residual memiliki nilai yang normal. Untuk melihat normalitas residual, peneliti menggunakan dua cara, yakni dengan analisis grafik dan uji Kolmogorov-Smirnov dengan melihat nilai Kolmogorov-Smirnov $Z$ dan nilai Asymp. Sig. pada hasil pengujian. Hasil pengujian normalitas residual disajikan pada Gambar 1 dan Tabel 2 berikut.

\section{Normal P-P Plot of Regression Standardized Residual}

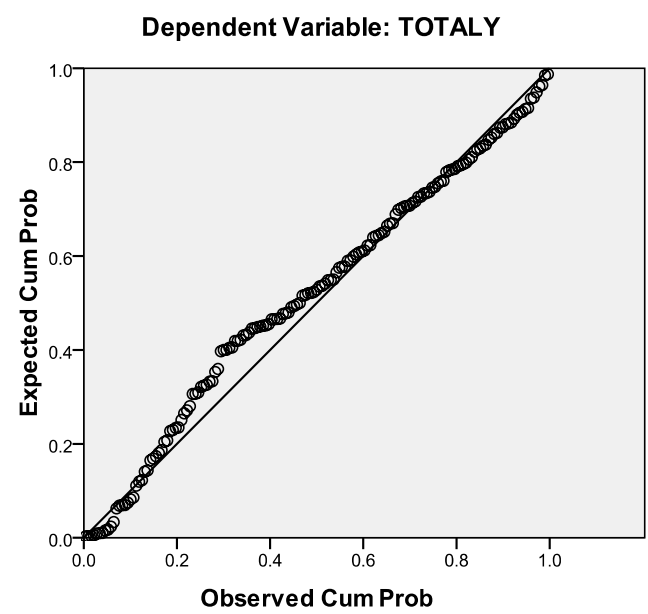

Gambar 1 Hasil Uji Normalitas Sumber: Output Pengolahan Data dengan SPSS 
Analisis grafik dalam Gambar 1 dilakukan dengan membandingkan antara plotting residual dan garis diagonal. Terlihat bahwa plotting data residual mendekati garis lurus diagonal, sehingga model regresi dalam penelitian ini adalah fit (baik) dan dapat dinyatakan pula bahwa distribusi data residual normal. Distribusi normal akan membentuk suatu garis lurus diagonal, sehingga semakin plotting data residual mendekati garis lurus diagonal tersebut, maka suatu model regresi dikatakan baik dan distribusi data residual bersifat normal.

Selain menggunakan analisis grafik, pengujian normalitas residual juga dapat dilakukan dengan melihat nilai Kolmogorov-Smirnov Z dan nilai Asymp. Sig. yang disajikan pada Tabel 2 berikut.

Tabel 2 Hasil Uji Normalitas

One-Sample Kolmogorov-Smirnov Test

\begin{tabular}{|ll|r|}
\hline & & $\begin{array}{c}\text { Unstandardized } \\
\text { Residual }\end{array}$ \\
\hline $\mathrm{N}$ & Mean & 165 \\
Normal Parameters & $\mathrm{a}, \mathrm{b}$ & .0000000 \\
& Std. Deviation & 6.74355844 \\
Most Extreme Differences & Absolute & .105 \\
& Positive & .040 \\
& Negative & -.105 \\
Kolmogorov-Smirnov $Z$ & & 1.350 \\
Asymp. Sig. (2-tailed) & & .052 \\
\hline
\end{tabular}

a. Test distribution is Normal.

b. Calculated from data.

Sumber: Output Pengolahan Data dengan SPSS

Pada Tabel 2, terlihat bahwa nilai Kolmogorov-Smirnov Z sebesar 1.350 dan nilai Asymp. Sig. sebesar 0.052. Hal ini menunjukkan bahwa kedua nilai tersebut memiliki nilai di atas tingkat signifikan yaitu sebesar 5\% atau 0.05 , sehingga dinyatakan bahwa distribusi data residual normal. Dengan demikian, berdasarkan uji normalitas residual yang dilakukan baik dengan analisis grafik maupun uji Kolmogorov-Smirnov, kedua metode tersebut menunjukkan hasil pengujian yang sama dan dapat disimpulkan bahwa distribusi data residual pada penelitian ini adalah normal.

\section{Uji Multikolinearitas}

Uji multikolinearitas bertujuan untuk mengetahui apakah pada suatu model regresi terdapat korelasi antar variabel independen. Uji multikolinearitas perlu dilakukan karena jumlah variabel independen (bebas) dalam penelitian ini berjumlah empat buah (lebih dari satu). Uji multikolinearitas pada penelitian ini dilakukan dengan melihat Variance Inflation Factor (VIF) dan tolerance yang disajikan pada Tabel 3 berikut ini. 
Tabel 3 Hasil Uji Multikolinearitas

Coefficients $^{\mathrm{a}}$

\begin{tabular}{|r|r|r|}
\hline \multirow{2}{*}{ Model } & \multicolumn{2}{|c|}{ Collinearity Statistics } \\
\cline { 2 - 3 } & Tolerance & VIF \\
\hline $1 \quad$ (Constant) & & \\
TOTALKP & .780 & 1.281 \\
TOTALKTP & .994 & 1.006 \\
TOTALKLP & .970 & 1.031 \\
TOTALGK & .792 & 1.262 \\
\hline
\end{tabular}

a. Dependent Variable: TOTALY

Sumber: Output Pengolahan Data dengan SPSS

Berdasarkan hasil uji multikolinearitas pada Tabel 3 tersebut, dapat disimpulkan bahwa nilai tolerance pada masing-masing variabel independen dalam penelitian ini lebih besar dari 0.1. Demikian pula dengan nilai VIF, dimana keempat variabel independen tersebut memiliki nilai kurang dari 10 . Hal ini berarti bahwa di antara variabel independen yang terdapat dalam penelitian ini tidak terjadi korelasi. Dengan kata lain, diantara variabel-variabel independen tersebut tidak terjadi multikolinearitas.

\section{Uji Autokorelasi}

Uji autokorelasi bertujuan untuk mengetahui ada atau tidaknya korelasi yang terjadi antara residual pada satu pengamatan dengan pengamatan lain pada model regresi. Pada pengujian autokorelasi dalam penelitian ini, peneliti menggunakan uji Durbin-Watson. Hasil pengujian autokorelasi disajikan pada Tabel 4 berikut ini.

Tabel 4 Hasil Uji Autokorelasi Model Summary ${ }^{\mathrm{b}}$

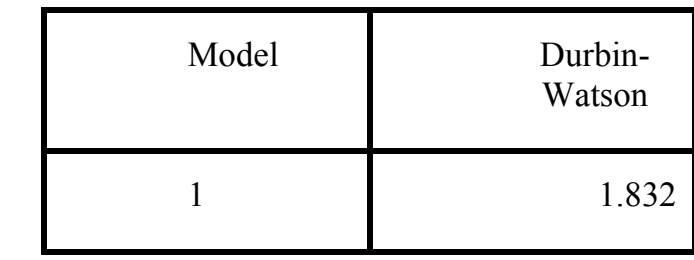

a. Predictors: (Constant), TOTALGK, TOTALKTP, TOTALKLP, TOTALKP

b. Dependent Variable: TOTALY

Sumber: Output Pengolahan Data dengan SPSS

Langkah pertama dalam uji autokorelasi adalah menentukan nilai $d_{L}$ dan $d_{U}$ dengan melihat Tabel Durbin-Watson, pada $\alpha=5 \%, K=4$, sehingga diperoleh nilai $\mathrm{d}_{\mathrm{L}}=1.6960$ dan nilai $\mathrm{d}_{\mathrm{U}}=1.7953$. Nilai $\mathrm{K}$ adalah jumlah variabel independen yang terdapat dalam penelitian ini yaitu empat buah, sedangkan nilai $\mathrm{n}=165$ (dimana $\mathrm{n}$ merupakan jumlah responden). Sehingga, nilai $4-\mathrm{d}_{\mathrm{U}}=4-1.7953=2.2047$ dan nilai $4-\mathrm{d}_{\mathrm{L}}=4-1.6960=2.304$. Dengan demikian, nilai Durbin-Watson pada Tabel 4.14 sebesar 1.832 berada di antara $\mathrm{d}_{\mathrm{U}}$ dan $4-\mathrm{d}_{\mathrm{U}}$, yaitu $1.7953<1.832<2.2047$. Jadi, dapat disimpulkan bahwa tidak terjadi autokorelasi pada model regresi dalam penelitian ini. 


\section{Uji Heteroskedastisitas}

Uji heteroskedastisitas digunakan untuk mengetahui ada atau tidaknya ketidaksamaan varian dari residual pada model regresi. Pengujian heteroskedastisitas pada penelitian ini dilakukan dengan dua cara, yaitu dengan melihat grafik scatterplot dan uji Glejser yang akan disajikan pada Gambar 2 dan Tabel 5 berikut ini.

Scatterplot

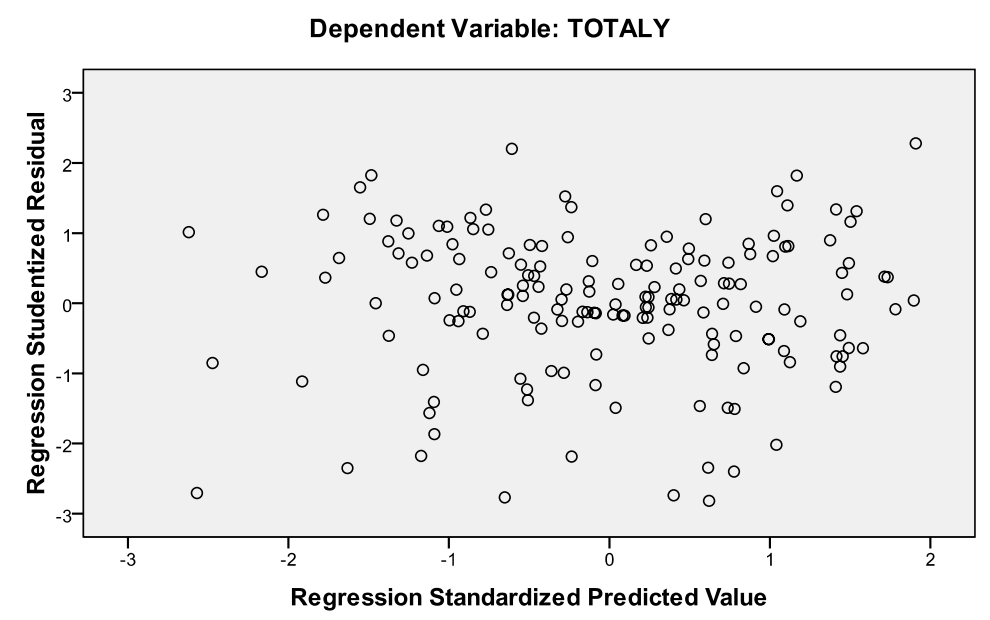

Gambar 2 Hasil Uji Heteroskedastisitas

Sumber: Output Pengolahan Data dengan SPSS

Berdasarkan scatterplot tersebut, terlihat bahwa titik-titik menyebar secara acak, baik di bagian atas angka nol maupun di bagian bawah angka nol dari sumbu vertikal atau sumbu Y. Dengan demikian, dapat disimpulkan bahwa tidak terjadi heteroskedastisitas dalam model regresi ini. Untuk memperoleh keakuratan dari hasil pengujian heteroskedastisitas dalam penelitian ini, peneliti melakukan uji Glejser melalui regresi nilai absolut residual dengan variabel independennya. Hal tersebut dilakukan karena dalam analisis grafik scatterplot, terdapat kelemahan yang dapat memengaruhi interpretasi hasil pengujian heteroskedastisitas. Hasil uji heteroskedastisitas dengan uji Glejser disajikan dalam Tabel 5 berikut.

Tabel 5 Hasil Uji Heteroskedastisitas dengan Uji Glejser

Coefficients $^{\mathrm{a}}$

\begin{tabular}{|c|c|c|c|c|c|c|c|c|}
\hline \multirow{2}{*}{\multicolumn{2}{|c|}{ Model }} & \multicolumn{2}{|c|}{ Unstandardized Coefficients } & \multirow{2}{*}{$\begin{array}{c}\text { Standardized } \\
\text { Coefficients } \\
\text { Beta }\end{array}$} & \multirow[b]{2}{*}{$\mathrm{t}$} & \multirow[b]{2}{*}{ Sig. } & \multicolumn{2}{|c|}{ Collinearity Statistics } \\
\hline & & B & Std. Error & & & & Tolerance & VIF \\
\hline 1 & (Constant) & 10.063 & 2.771 & & 3.632 & .000 & & \\
\hline & TOTALKP & -.119 & .068 & -.151 & -1.745 & .083 & .780 & 1.28 \\
\hline & TOTALKTP & -.070 & .074 & -.073 & -.949 & .344 & .994 & 1.00 \\
\hline & TOTALKLP & .243 & .130 & .145 & 1.863 & .064 & .970 & 1.03 \\
\hline & TOTALGK & -.086 & .070 & -.106 & -1.233 & .219 & .792 & 1.26 \\
\hline
\end{tabular}

a. Dependent Variable: abresid

Sumber: Output Pengolahan Data dengan SPSS 
Berdasarkan hasil uji heteroskedastisitas melalui uji Glejser pada Tabel 5 tersebut, dapat dilihat bahwa nilai Sig. pada masing-masing variabel bernilai lebih dari 0.05. Dengan demikian, hal tersebut menunjukkan bahwa tidak terjadi heteroskedastisitas dalam model regresi pada penelitian ini, yang berarti varians dari residual satu pengamatan ke pengamatan lain adalah tetap. Atau dengan kata lain, variabel-variabel independen yang terdapat dalam penelitian ini mengalami homokedastisitas.

\section{Uji Hipotesis}

\section{Uji Signifikansi Simultan (Uji F)}

Uji $\mathrm{F}$ dalam penelitian ini bertujuan untuk mengetahui apakah konflik peran, ketidakjelasan peran, kelebihan peran, dan gaya kepemimpinan mempunyai pengaruh signifikan secara bersamasama terhadap kinerja auditor. Uji $\mathrm{F}$ ini dilakukan dengan dua cara, yaitu dengan membandingkan nilai Sig. dengan nilai signifikansi sebesar 0.05 serta dengan membandingkan nilai $F$ hitung yang terdapat dalam tabel anova dengan nilai F tabel. Hasil uji F disajikan dalam Tabel 6 berikut ini.

Tabel 6 Hasil Uji Signifikansi Simultan (Uji F)

\begin{tabular}{|c|c|c|c|c|c|c|}
\hline \multicolumn{7}{|c|}{ ANOVA $^{b}$} \\
\hline & & Sum of Squares & $\mathrm{df}$ & Mean Square & $\mathrm{F}$ & Sig. \\
\hline \multirow[t]{3}{*}{1} & Regression & 326.514 & 4 & 81.628 & 1.751 & $.141^{\mathrm{a}}$ \\
\hline & Residual & 7457.995 & 160 & 46.612 & & \\
\hline & Total & 7784.509 & 164 & & & \\
\hline
\end{tabular}

Sumber: Output Pengolahan Data dengan SPSS

Dalam pengujian ini, hipotesis alternatif $(\mathrm{Ha})$ yang digunakan adalah terdapat pengaruh signifikan antara variabel independen secara bersama-sama terhadap variabel dependen. Sedangkan hipotesis nol (Ho), yang digunakan adalah tidak terdapat pengaruh signifikan antara variabel independen secara bersama-sama terhadap variabel dependen. Berdasarkan hasil uji signifikansi simultan (uji F) pada Tabel 6, dapat disimpulkan bahwa nilai F hitung sebesar 1.751 dan nilai Sig. sebesar 0.141. Hal ini menunjukkan bahwa nilai $\mathrm{F}$ hitung lebih kecil dari nilai $\mathrm{F}$ tabel yang bernilai 2.43. Selain itu, nilai Sig. memiliki nilai yang lebih besar dari nilai signifikansi yang telah ditetapkan sebesar 0.05. Dengan demikian, dapat dinyatakan bahwa Ha ditolak. Dengan kata lain, konflik peran, ketidakjelasan peran, kelebihan peran, dan gaya kepemimpinan tidak mempunyai pengaruh signifikan secara bersama-sama terhadap kinerja auditor.

\section{Uji Koefisien Determinasi $\left(\mathrm{R}^{2}\right)$}

Koefisien determinasi $\left(\mathrm{R}^{2}\right)$ berguna untuk mengukur seberapa besar variabel independen dapat menjelaskan variasi variabel dependen dan sisanya yang tidak dapat dijelaskan, yang merupakan bagian dari variasi variabel lain yang tidak dimasukkan kedalam model. Uji ini dilakukan dengan melihat nilai dari $R$ Square yang disajikan pada Tabel 7 berikut ini. 


\begin{tabular}{|l|r|r|r|r|r|}
\hline Model & \multicolumn{1}{|c|}{ R } & R Square & Adjusted R Square & $\begin{array}{c}\text { Std. Error of the } \\
\text { Estimate }\end{array}$ & Durbin-Watson \\
\hline 1 & $.205^{\mathrm{a}}$ & .042 & .018 & 6.827 & 1.832 \\
\hline
\end{tabular}
a. Predictors: (Constant), TOTALGK, TOTALKTP, TOTALKLP, TOTALKP
b. Dependent Variable: TOTALY

Sumber: Output Pengolahan Data dengan SPSS

Berdasarkan hasil uji koefisien determinasi $\left(\mathrm{R}^{2}\right)$ pada Tabel 7, dapat dilihat bahwa nilai $R$ Square sebesar 0.042 . Besarnya koefisien ini bernilai antara 0 sampai 1 . Bila nilai $R$ Square lebih mendekati angka 0 , berarti kemampuan variabel-variabel independen dalam menjelaskan variasi variabel dependen sangat terbatas. Sebaliknya, apabila nilai $R$ Square mendekati nilai 1, berarti variabel-variabel independen mampu memberikan hampir semua informasi yang dibutuhkan untuk memprediksi variasi variabel dependen. Hal ini berarti bahwa variabel-variabel independen dalam penelitian ini memengaruhi variabel dependen sebesar 4.2\%. Dengan kata lain, konflik peran, ketidakjelasan peran, kelebihan peran, dan gaya kepemimpinan memengaruhi kinerja auditor sebesar $4.2 \%$, sedangkan sisanya sebesar $95.8 \%$ dipengaruhi oleh faktor-faktor atau variabel-variabel lain yang tidak dimasukkan dalam model regresi pada penelitian ini.

\section{Uji Signifikan Parameter Individual (Uji t)}

Pengujian ini digunakan untuk mengetahui secara individual pengaruh konflik peran, ketidakjelasan peran, kelebihan peran, dan gaya kepemimpinan terhadap kinerja auditor. Berikut disajikan hasil dari uji signifikan parameter individual (uji t) yang dapat dilihat pada tabel coefficients berikut ini.

Tabel 8 Hasil Uji Signifikan Parameter Individual (Uji t)

\begin{tabular}{|c|c|c|c|c|c|c|c|c|}
\hline \multirow{2}{*}{\multicolumn{2}{|c|}{ Model }} & \multicolumn{2}{|c|}{ Unstandardized Coefficients } & \multirow{2}{*}{$\begin{array}{c}\text { Standardized } \\
\text { Coefficients } \\
\text { Beta }\end{array}$} & \multirow[b]{2}{*}{$\mathrm{t}$} & \multirow[b]{2}{*}{ Sig. } & \multicolumn{2}{|c|}{ Collinearity Statistics } \\
\hline & & $\mathrm{B}$ & Std. Error & & & & Tolerance & VIF \\
\hline \multirow[t]{5}{*}{1} & (Constant) & 53.437 & 4.403 & & 12.138 & .000 & & \\
\hline & TOTALKP & .104 & .109 & .084 & .958 & .339 & .780 & 1.281 \\
\hline & TOTALKTP & -.236 & .117 & -.156 & -2.012 & .046 & .994 & 1.006 \\
\hline & TOTALKLP & -.175 & .207 & -.066 & -.844 & .400 & .970 & 1.031 \\
\hline & TOTALGK & .083 & .111 & .065 & .747 & .456 & .792 & 1.262 \\
\hline
\end{tabular}

a. Dependent Variable: TOTALY

Sumber: Output Pengolahan Data dengan SPSS

Berdasarkan hasil uji signifikan parameter individual (uji t) pada Tabel 8, dengan melihat nilai unstandardized coefficient pada kolom $\mathrm{B}$, maka persamaan regresi dalam penelitian ini dinyatakan sebagai berikut:

$$
\mathrm{Y}=53.437+0.104 \mathrm{KP}-0.236 \mathrm{KTP}-0.175 \mathrm{KLP}+0.083 \mathrm{GK}+\mathrm{e}
$$


Persamaan regresi tersebut dapat diinterpretasikan sebagai berikut: (1) Besarnya konstanta adalah 53.437, yang berarti apabila tidak ada kenaikan pada variabel konflik peran, ketidakjelasan peran, kelebihan peran, dan gaya kepemimpinan maka nilai variabel kinerja auditor adalah sebesar 53.437. (2) Koefisien regresi variabel konflik peran bernilai 0.104 berarti setiap penambahan satu nilai pada variabel konflik peran, akan menaikkan kinerja auditor sebesar 0.104 dengan asumsi variabel lain adalah tetap. (3) Koefisien regresi variabel ketidakjelasan peran bernilai -0.236 berarti setiap penambahan satu nilai pada variabel ketidakjelasan peran, akan menurunkan kinerja auditor sebesar 0.236 dengan asumsi variabel lain adalah tetap. Koefisien tersebut bernilai negatif, berarti terdapat hubungan negatif antara variabel ketidakjelasan peran dengan kinerja auditor. (4) Koefisien regresi variabel kelebihan peran bernilai -0.175 berarti setiap penambahan satu nilai pada variabel kelebihan peran, akan menurunkan kinerja auditor sebesar 0.175 dengan asumsi variabel lain adalah tetap. Koefisien tersebut bernilai negatif, berarti terdapat hubungan negatif antara variabel kelebihan peran dengan kinerja auditor. (5) Koefisien regresi variabel gaya kepemimpinan bernilai 0.083 berarti setiap penambahan satu nilai pada variabel gaya kepemimpinan, akan menaikkan kinerja auditor sebesar 0.083 dengan asumsi variabel lain adalah tetap.

Uji t yang dilakukan dalam penelitian ini dilakukan dengan membandingkan nilai t hitung yang terdapat dalam tabel 4.18 dengan $t$ tabel yang diperoleh dalam hasil pengolahan data yaitu sebesar 1.97. Selain itu, uji t ini dilakukan pula dengan melihat nilai Sig. yang terdapat pada Tabel 8, kemudian dibandingkan dengan tingkat signifikansi sebesar 0.05. Apabila nilai Sig. lebih besar dari 0.05, maka Ha akan ditolak, sebaliknya apabila nilai Sig. lebih kecil dari 0.05 maka Ha akan diterima dan Ho akan ditolak. Demikian pula apabila nilai t hitung lebih kecil dari nilai $t$ tabel, maka Ha akan ditolak, sebaliknya apabila nilai t hitung lebih besar dari nilai $t$ tabel, maka Ha akan diterima dan Ho akan ditolak.

Variabel konflik peran memiliki nilai t hitung sebesar 0.958 dimana hal ini bernilai lebih kecil daripada nilai $t$ tabel sebesar 1.97 serta nilai Sig. sebesar 0.339 yang memiliki nilai lebih besar daripada tingkat signifikan sebesar 0.05 . Dengan demikian, dapat dinyatakan bahwa $\mathrm{Ha}_{1}$ ditolak, yang berarti bahwa konfik peran tidak berpengaruh secara signifikan terhadap kinerja auditor di Kantor Akuntan Publik wilayah DKI Jakarta. Hal ini mungkin terjadi karena konflik peran yang dihadapi auditor tidak menimbulkan perasaan tertekan dan serba salah dalam melaksanakan tugas pekerjaannya. Kondisi tersebut dianggap sebagai suatu tuntutan dalam profesi auditor serta tanggung jawab yang lumrah terjadi dalam praktik dunia kerja dan mau / tidak mau harus dihadapi oleh auditor tanpa menimbulkan pengaruh terhadap kinerjanya. Oleh karena itu, seorang auditor dituntut untuk memiliki sikap mental yang tangguh dalam menjalankan profesinya sebagai seorang akuntan publik. Hasil penelitian mengenai konflik peran ini dinyatakan tidak konsisten dengan penelitian yang dilakukan oleh Agustina (2009), Fanani et al. (2006), Viator (2001), Fisher (2001), dan Fried (1998).

Variabel ketidakjelasan peran memiliki nilai t hitung sebesar 2.012 dimana hal ini bernilai lebih besar daripada nilai t tabel sebesar 1.97 serta nilai Sig. sebesar 0.046 yang memiliki nilai lebih kecil daripada tingkat signifikan sebesar 0.05. Dengan demikian, dapat dinyatakan bahwa $\mathrm{Ha}_{2}$ diterima, yang berarti bahwa ketidakjelasan peran memiliki kontribusi atau berpengaruh secara signifikan terhadap kinerja auditor di Kantor Akuntan Publik wilayah DKI Jakarta. Hal ini mungkin terjadi karena apabila seorang auditor tidak mengetahui dengan jelas serta bingung mengenai apa yang harus dilakukan dan bagaimana ia melakukan suatu pekerjaan, maka tujuan dari suatu pekerjaan tersebut menjadi tidak tercapai sehingga berpengaruh terhadap hasil kerja auditor yang tidak sesuai dengan harapan. Hasil penelitian mengenai ketidakjelasan peran ini konsisten terhadap penelitian yang dilakukan oleh Agustina (2009), Fisher (2001), dan Fried (1998), tetapi tidak konsisten dengan penelitian yang dilakukan oleh Fanani et al. (2006) dan Viator (2001) yang menyatakan bahwa tidak terdapat pengaruh dari ketidakjelasan peran terhadap kinerja auditor.

Variabel kelebihan peran memiliki nilai t hitung sebesar 0.844 dimana hal ini bernilai lebih kecil daripada nilai t tabel sebesar 1.97 serta nilai Sig. sebesar 0.400 yang memiliki nilai lebih besar 
daripada tingkat signifikan sebesar 0.05. Dengan demikian, dapat dinyatakan bahwa $\mathrm{Ha}_{3}$ ditolak, yang berarti bahwa kelebihan peran tidak berpengaruh secara signifikan terhadap kinerja auditor di Kantor Akuntan Publik wilayah DKI Jakarta. Hal ini mungkin terjadi karena kelebihan peran yang dirasakan oleh auditor dianggap sebagai suatu hal yang biasa terjadi yang merupakan ciri khas dari pekerjaan pada Kantor Akuntan Publik. Sebelum memutuskan untuk terjun dalam profesi auditor, seorang auditor telah mempertimbangkan konsekuensi dari pekerjaannya dimana suatu kelebihan peran seperti pekerjaan yang banyak, bekerja berdasarkan deadline yang telah ditentukan, dan waktu kerja yang berlebihan (overtime) sebagai ciri khas pekerjaan dari seorang auditor independen di Kantor Akuntan Publik. Oleh karena itu, auditor dapat menjalankan tugasnya tanpa menganggap kelebihan peran sebagai suatu beban atau penghalang yang dapat memengaruhi kinerjanya. Hasil penelitian mengenai kelebihan peran ini tidak konsisten dengan penelitian yang dilakukan oleh Agustina (2009).

Variabel gaya kepemimpinan memiliki nilai t hitung sebesar 0.747 dimana hal ini bernilai lebih kecil daripada nilai t tabel sebesar 1.97 serta nilai Sig. sebesar 0.456 yang memiliki nilai lebih besar daripada tingkat signifikan sebesar 0.05 . Dengan demikian, dapat dinyatakan bahwa $\mathrm{Ha}_{4} \mathrm{ditolak}_{\text {, }}$ yang berarti bahwa gaya kepemimpinan tidak berpengaruh secara signifikan terhadap kinerja auditor di Kantor Akuntan Publik wilayah DKI Jakarta. Hal ini mungkin terjadi dengan alasan karena sebaik apapun gaya kepemimpinan yang terdapat pada Kantor Akuntan Publik, apabila tidak didukung oleh kerja keras serta usaha dari auditor itu sendiri, maka kinerja yang memuaskan tidak akan dapat tercapai. Pemimpin yang terdapat dalam KAP hanya sebatas memberikan kebijakan, panduan, arahan, serta dorongan dalam bekerja, namun keberhasilan dari suatu pekerjaan amat ditentukan oleh pribadi auditor itu sendiri. Hasil penelitian mengenai gaya kepemimpinan ini konsisten dengan penelitan yang dilakukan oleh Marganingsih (2009), tetapi tidak konsisten dengan penelitian yang dilakukan oleh Trisnaningsih (2007).

\section{SIMPULAN}

Berdasarkan pembahasan, pengujian, serta analisis yang telah dilakukan dalam penelitian ini, maka dapat ditarik simpulan sebagai berikut. Pertama, tidak terdapat pengaruh signifikan antara konfik peran terhadap kinerja auditor di Kantor Akuntan Publik wilayah DKI Jakarta. Dari hasil penelitian tersebut, konflik peran dianggap sebagai suatu tuntutan dalam profesi auditor serta tanggung jawab yang lumrah terjadi dalam praktik dunia kerja yang harus dihadapi oleh auditor tanpa menimbulkan pengaruh terhadap kinerjanya. Oleh karena itu, seorang auditor dituntut untuk memiliki sikap mental yang tangguh dalam menjalankan profesinya sebagai seorang akuntan publik. Hasil penelitian mengenai konflik peran ini dinyatakan tidak konsisten dengan penelitian yang dilakukan oleh Agustina (2009), Fanani et al. (2006), Viator (2001), Fisher (2001), dan Fried (1998).

Kedua, terdapat pengaruh signifikan antara ketidakjelasan peran terhadap kinerja auditor di Kantor Akuntan Publik wilayah DKI Jakarta. Dari hasil penelitian tersebut, apabila seorang auditor tidak mengetahui dengan jelas serta bingung mengenai apa yang harus dilakukan dan bagaimana ia melakukan suatu pekerjaan, tujuan dari suatu pekerjaan tersebut menjadi tidak tercapai sehingga berpengaruh terhadap hasil kerja auditor yang tidak sesuai dengan harapan. Hasil penelitian mengenai ketidakjelasan peran ini konsisten terhadap penelitian yang dilakukan oleh Agustina (2009), Fisher (2001), dan Fried (1998), tetapi tidak konsisten dengan penelitian yang dilakukan oleh Fanani et al. (2006) dan Viator (2001).

Ketiga, tidak terdapat pengaruh signifikan antara kelebihan peran terhadap kinerja auditor di Kantor Akuntan Publik wilayah DKI Jakarta. Pertimbangan hal tersebut karena sebelum memutuskan untuk terjun dalam profesi auditor, seorang auditor telah mempertimbangkan konsekuensi dari pekerjaannya dimana suatu kelebihan peran seperti pekerjaan yang banyak, bekerja berdasarkan deadline yang telah ditentukan, dan waktu kerja yang berlebihan (overtime) sebagai ciri khas 
pekerjaan dari seorang auditor independen di Kantor Akuntan Publik. Oleh karena itu, auditor dapat menjalankan tugasnya tanpa menganggap kelebihan peran sebagai suatu beban atau penghalang yang dapat memengaruhi kinerjanya. Hasil penelitian mengenai kelebihan peran ini tidak konsisten dengan

penelitian yang dilakukan oleh Agustina (2009).

Keempat, tidak terdapat pengaruh signifikan antara gaya kepemimpinan terhadap kinerja auditor di Kantor Akuntan Publik wilayah DKI Jakarta. Hal tersebut karena sebaik apapun gaya kepemimpinan yang terdapat pada Kantor Akuntan Publik, jika tidak didukung oleh kerja keras serta usaha dari auditor itu sendiri, kinerja yang memuaskan tidak akan dapat tercapai. Pemimpin yang terdapat dalam KAP hanya sebatas memberikan kebijakan, panduan, arahan, serta dorongan dalam bekerja, namun keberhasilan dari suatu pekerjaan amat ditentukan oleh pribadi auditor itu sendiri. Hasil penelitian mengenai gaya kepemimpinan ini konsisten dengan penelitan yang dilakukan oleh Marganingsih (2009), tetapi tidak konsisten dengan penelitian yang dilakukan oleh Trisnaningsih (2007).

Kelima, konflik peran, ketidakjelasan peran, kelebihan peran, dan gaya kepemimpinan memengaruhi kinerja auditor sebesar $4.2 \%$, sedangkan sisanya sebesar $95.8 \%$ dipengaruhi oleh faktorfaktor atau variabel-variabel lain yang tidak dimasukkan dalam model regresi pada penelitian ini. Dan terakhir, konflik peran, ketidakjelasan peran, kelebihan peran, dan gaya kepemimpinan tidak mempunyai pengaruh signifikan secara simultan terhadap kinerja auditor di Kantor Akuntan Publik wilayah DKI Jakarta.

\section{DAFTAR PUSTAKA}

Agustina, L. (2009). Pengaruh Konflik Peran, Ketidakjelasan Peran, dan Kelebihan Peran terhadap Kepuasan Kerja dan Kinerja Auditor. Jurnal Akuntansi. 1(1): 40-69.

Amilin \& Dewi, R. (2008). Pengaruh Komitmen Organisasi Terhadap Kepuasan Kerja Akuntan Publik dengan Role Stress Sebagai Variabel Moderating. Jurnal Akuntansi Indonesia. 12(1): 13-24.

Assegaf, Y. A. (2005). Pengaruh Konflik Peran dan Stres Kerja terhadap Komitmen Organisasi. Jurnal Akuntansi dan Bisnis. 5(2): 91-106.

Cahyono D. \& Ghozali, I. (2002). Pengaruh Jabatan, Budaya Organisasi dan Konflik Peran terhadap Hubungan Kepuasan Kerja dengan Komitmen Organisasi: Studi Empiris di Kantor Akuntan Publik. Jurnal Riset Akuntansi Indonesia. 5(3): 341-361.

Fanani, Z., Hanif, R.A., \& Subroto, B. (2008). Pengaruh Struktur Audit, Konflik Peran, dan Ketidakjelasan Peran Terhadap Kinerja Auditor. Jurnal Akuntansi dan Keuangan Indonesia. 5(2): 139-155.

Fisher, R. T. (2001). Role Stress, The Type A Behavior Pattern, and External Auditor Job Satisfaction and Performance. Journal of Behavior Research In Accounting. 13: 143-171.

Ghozali, I. (2006). Aplikasi Analisis Multivariate dengan Program SPSS. Cetakan IV. Semarang: Badan Penerbit Universitas Diponegoro.

HS, Widjono. (2007). Bahasa Indonesia Mata Kuliah Pengembangan Kepribadian di Perguruan Tinggi. Jakarta: Grasindo. 
Mulyadi. (1998). Auditing jilid 1 (edisi 5). Jakarta: Salemba Empat.

Rahman, S., Nasir, H. M., \& Handayani, R. S. (2007). Pengaruh Sistem Pengukuran Kinerja terhadap Kejelasan Peran, Pemberdayaan Psikologis dan Kinerja Manajerial. Paper dipresentasikan pada Simposium Nasional Akuntansi X, Makasar.

Robbins, P. S., \& Judge, T. A. Alih bahasa oleh Diana Angelica. (2008). Perilaku Organisasi jilid 1 (edisi 12). Jakarta: Salemba Empat.

Santoso, S. (2003). Buku Latihan SPSS Statistik Multivariat. Jakarta: Elex Media Komputindo.

Sarjono, H., \& Julianita, W. (2011). SPSS vs Lisrel, Sebuah Pengatar, Aplikasi Untuk Reset jilid 1 (edisi 1). Jakarta: Salemba Empat.

Supranto, J. (2008). Statistik Teori dan Aplikasi jilid 1 (edisi 7). Jakarta: Erlangga.

Surya, R., \& Hananto, S. T. (2004). Pengaruh Emotional Quotient Auditor Terhadap Kinerja Auditor di Kantor Akuntan Publik. Perspektif. 9(1): 33-40.

Trisnaningsih, S. (2007). Independensi Auditor dan Komitmen Organisasi sebagai Mediasi Pengaruh Pemahaman Good Governance, Gaya Kepemimpinan dan Budaya Organisasi Terhadap Kinerja Auditor. Paper dipresentasikan pada Simposium Nasional Akuntansi X, Makasar.

Utami, I., Syafruddin, M., \& Handayani, R. S. (2006). Pengaruh Tekanan Etis Terhadap Konflik Organisasional-Profesional dan Workoutcomes (Studi Empiris Pada Akuntan Publik seIndonesia. Paper dipresentasikan pada Simposium Nasional Akuntansi IX, Padang. 